2 Dinarello CA. Interleukin-1. Rev Infect Dis 1984; 6: 51-95.

3 Strieter R, Chensue SW, Basha M, et al. Human alveolar macrophage gene expression of IL-8 by tumour necrosis factor $\alpha$ and interleukin $-1 \beta$. Am 7 Respir Cell Mol Biol 1990; 2: 321-5.

4 Ming WJI, Bersani L, Mantovani A. Tumour necrosis factor is chemotactic for monocytes and polymorphunclear leukocytes. F Immunol 1987; 138: $1469-74$

5 Klebanoff SJ, Vadas MA, Harlam JM. Stimulation of neutrophils by tumour necrosis factor $\alpha$. F Immunol 1986; 136: 4220-5.

6 Pohlman TH, Stanness KA, Beatty PG, Ochs HD, Harlan JM. An endothelia cell surface factor(s) induced in vitro by lipopolysaccharide, interleukinand tumour necrosis factor $\alpha$ increases neutrophil adherence by a CDw18 dependent mechanism. F Immunol 1986; 136: 4548-53.

7 Baggiolini M, Walz A, Kunkel SL. Neutrophil-activating peptide-1/ interleukin-8, a novel cytokine that activates neutrophils. $\mathcal{F}$ Clin Invest 1989 ; 84: 1045-9.

8 Male D, Champion B, Cooke A, Owen M. Inflammation. Advanced immunology. London: Gower Medical Publishing, 1991: 16.9.

9 Wilmott RW, Kassab JT, Kilian PL, Benjamin WR, Douglas SD, Wood RE. Increased levels of interleukin-1 in bronchoalveolar washings from children Increased levels of interleukin-1 in bronchoalveolar washings from children

10 Wilmott RW, Wood RE, Frenzke M. Interleukin-8 concentrations in bronchoalveolar lavage fluid from children with cystic fibrosis. Am Rev Respir Dis 1992; 145: A234.

11 Suter S, Schaad UB, Roux-Lombard P, Girardin E, Grau G, Dayer JM Relationship between tumour necrosis factor $\alpha$ and granulocyte elastaseelastase- $\alpha$-1-proteinase inhibitor complexes in plasma of patients with cystic fibrosis. Am Rev Respir Dis 1989; 140: 1640-4.

12 Dagli E, Warner JA, Besley CR, Warner JO. Raised soluble interleukin-2 receptor concentrations in cystic fibrosis patients with and without evidence receptor concentrations in cystic fibrosis patients
of lung disease. Arch Dis Child 1992; 67: 479-81.

13 Azzawi M, Johnston PW, Majumdar S, Kay AB, Jeffery PK. T-lymphocytes and activated eosinophils in airway mucosa in fatal asthma and cystic fibrosis. and activated eosinophils in airway mucosa

14 Klaus GGB. In: Rickwood D, Male D, eds. Immunoglobulin synthesis. $B-L y$ mphocytes. Oxford: IRL at Oxford University Press 1990; 3: 4.4 .

15 Wheeler WB, Williams M, Matthews WJ, Colten HR. Progression of cystic fibrosis lung disease as a function of serum immunoglobulin $G$ levels: a 5 year longitudinal study. F Pediatr 1984; 104: 695-9.

16 Moss RB, Hsu Yp, Sullivan MM, Lewiston NJ. Altered antibody isotype in cystic fibrosis: a possible role in opsonic deficiency. Pediatr Res 1986; 20 453-9.

17 Schiotz PO, Nielsen H, Hoiby N, Glikmann G, Svehag SE. Immune complexes in sputum of patients with cystic fibrosis suffering from chronic Pseudomonas aeruginosa lung infection. Acta Pathologica Microbiologica Scandinavica $(C)$ 1978; 86: 37-40.

18 Wisnieski JJ, Todd EW, Fuller RK, et al. Immune complexes and complement abnormalities in patients with cystic fibrosis. Am Rev Respir Dis 1985. 132: $770-6$.

19 Fick RB Jr, Robbins RA, Squier SU, Schoderbek WE, Russ WD. Complement activation in cystic fibrosis respiratory fluids: in vivo and in vitro generation of $\mathrm{C} 5 \mathrm{a}$ and chemotactic activity. Pediatr Res 1986; 20: 1258-68.

20 Berger $M$. Inflammation in the lung in cystic fibrosis: a vicious cycle that does more harm than good? In: Moss RB, ed. Cystic fibrosis. Clin Rev Allergy 1990 7: $119-40$.

21 Meyer KC, Lewandoski JR, Zimmerman JJ, Nunely D, Calhoun WJ, Dopica GA. Human neutrophil elastase and elastase/ $\alpha 1$ antiprotease complex in cystic fibrosis. Am Rev Respir Dis 1991; 144: 580-5.

22 Bruce MC, Poncz L, Klinger J, Stern R, Tomashefski JF, Dearborn DG. Biochemical and pathological evidence for proteolytic destruction of lung connective tissue in cystic fibrosis. Am Rev Respir Dis 1985; 132: 529-35.

23 Doring G, Albus A, Hoiby N. Immunologic aspects of cystic fibrosis. Chest 1988; $94: 109 \mathrm{~s}-3$.

24 Kharazmi A. Interactions of Pseudomonas aeruginosa with the cells of the immune system. Antibiot Chemother 1989; 42: 42-9.
25 Lemen RJ, Gates AJ, Mathe AA, Waring WW, Hyman AL, Kadowitz PD. Relationships among digital clubbing, disease severity and serum prostaglandins $\mathrm{F}_{2 \alpha}$ and $\mathrm{E}$ concentrations in cystic fibrosis patients. Am Rev Respir Dis 1978; 117: 639-45.

26 Stead RJ, Barradas MA, Mikhailis DP, et al. Platelet hyperaggregability in cystic fibrosis. Prostaglandins, Leukotrienes Thromboxanes 1987; 26: 91-103.

27 Sampson AP, Spencer DA, Green CP, Piper PJ, Price JF. Leukotrienes in the sputum and urine of cystic fibrosis children. Br $\mathcal{F}$ Clin Pharmacol 1990; 30 861-9.

28 Carlstedt-Duke J, Bronnegard M, Strandvik B. Pathological regulation of arachidonic acid release in cystic fibrosis. The putative basic defect. Proc Nat Acad Sci USA 1986; 83: 9202-6.

29 Bauldry SA, McCall CE, Cousart SL, Bass DA. Tumour necrosis factor a priming of phospholipase $\mathrm{A}_{2}$ activation in human neutrophils. $\mathcal{F}$ Immunol priming of phospho

30 Roubin R, Elsas PP, Fiers W, Dessein AJ. Recombinant human TNFa enhances leukotriene synthesis in neutrophils and eosinophils stimulated by $\mathrm{Ca}^{++}$ionophore A23187. Clin Exp Immunol 1987; 70: 484-90.

31 Greally P, Hussein MJ, Cook AJ, Sampson AP, Piper PJ, Price JF. Sputum tumour necrosis factor- $\alpha$ and leukotriene concentrations in cystic fibrosis. Arch Dis Child 1993; 68: 389-92.

32 Neuber K, Hilger RA, Konig W. Interleukin-3, interleukin-8, FMLP and C5a enhance the release of leukotrienes from neutrophils of patients with atopic dermatitis. Immunology 1991; 73: 83-7.

33 Hong SC, Levine L. Inhibition of arachidonic acid release from cells as the biochemical action of anti-inflammatory corticosteroids. Proc Natl Acad Sci USA 1976; 73: 1730-4.

34 Balckwell GJ, Carnuccio R, Di Rosa M, Flower RJ, Parente L, Persico P. Macrocortin: a polypeptide causing the antiinflammatory effect of glucocorticoids. Nature 1980; 287: 147-9.

35 Sebaldt RJ, Sheller JR, Oates JA, Roberts LJ, Fitzgerald GA. Inhibition of eicosanoid synthesis by glucocorticoids. Proc Natl Acad Sci USA 1990; 87: 6974-8.

36 Seggev JS, Thornton WH, Edes TE. Serum $\mathrm{LTB}_{4}$ in patients with obstructive pulmonary disease. Chest 1991; 99: 289-91.

37 Scheimler RP. Effects of glucocorticoids on inflammatory cells relevant to their therapeutic applications to asthma. Am Rev Respir Dis 1990; 141: S59-69.

38 Gillis S, Crabtree GR, Smith KA. Glucocorticoid-induced inhibition of T cell growth factor production I. $\mathcal{F}$ Immunol 1979; 123: 1624-31.

39 Horst JH, Flad HD. Corticosteroid/interleukin-2 interactions: inhibition of binding of interleukin-2 to interleukin-2 receptors. Clin Exp Immunol 1987; 68: $156-62$.

40 Safirstein B, D'Souza MF, Simon G, Tai EHC, Pepys J. Five year follow up of allergic bronchopulmonary aspergillosis. Am Rev Respir Dis 1973; 108: allergic

41 Lewiston NJ, Moss RB. Circulating immune complexes decrease during corticosteroid therapy in cystic fibrosis. Pediatr Res 1982; 4: 354A.

42 Pantin CFA, Stead RJ, Hodson ME, Batten JC. Prednisolone in the treatmen of airflow obstruction in adults with cystic fibrosis. Thorax 1986; 41: 34-8.

43 Auerbach HS, Williams M, Kirkpatrick JA, Cotten HR. Alternate day prednisolone reduces the morbidity and improves pulmonary function in cystic fibrosis. Lancet 1985; ii: 686-8.

44 Donati MA, Haver K, Gerson W, Klein M, McLaughlin FJ, Wohl MEB. Long term alternate day prednisolone therapy in cystic fibrosis. Pediatr Pulmonol 1990; suppl 5: 277.

45 Rosenstein BJ, Eigen $\mathrm{H}$. Risks of alternate day prednisolone in patients with cystic fibrosis. Pediatrics 1991; 87: 245-6.

46 Schiøtz PO, Jørgensen M, Winge Flensborg E, et al. Chronic Pseudomonas aeruginosa lung infection in cystic fibrosis. Acta Paediatr Scand 1983; 72: 283-7.

47 Balough K, Fick R Jr, Weinberger M, McCubbin M, Ahrens R, Inflammation in early cystic fibrosis lung lesion: lack of correlation with infection. Am Rev Respir Dis 1992; 145: A689.

\section{Genetics of asthma}

\section{Asthma is heterogeneous}

Asthma is simply defined as labile airflow obstruction and is a heterogeneous syndrome whose causes include atopy, exposure to industrial toxin such as isocyanates, infection in small calibre airways in childhood, and cigarette smoking. In some older individuals, no external precipitant is identifiable and this has unjustifiably been termed intrinsic rather than idiopathic asthma.

This heterogeneity, the high frequency of asthma (with a life time prevalence of $10 \%$ ), and its variable severity make the analysis of genetic factors difficult. It is not surprising that it is regarded as a polygenic or multifactorial disorder. Thus the prevalence of diagnosed asthma in the first degree relatives of probands with intrinsic and extrinsic asthma is respectively 4.5 and $11 \cdot 3 \%$. ${ }^{1}$ First degree relatives (parents, siblings, and children) share on average one half of their genes and these prevalence figures do not approach mendelian predictions for a simple genetic disorder. Attempts to assay the disease phenotype by measurements of bronchial hyper-reactivity (a characteristic underlying abnormality in asthma that can be detected by exercise or methacholine challenge) provide no further evidence of a simple genetic effect.

\section{Atopy and IgE response}

The clearest indication of an important genetic effect on the development of asthma arises in relation to one of its principle causes, atopy. ${ }^{3}$ Atopy or allergic responsiveness to common but otherwise innocuous antigens, such as house dust mite particles or pollens, is mediated by the prolonged and exuberant production of IgE antibody to these agents. ${ }^{4}$ Clinical symptoms in the nose (rhinitis), bronchus (asthma), and skin (eczema) occur in variable combination and severity 
in different atopic individuals in whom allergen interaction with mucosal, mast cell bound IgE triggers a molecular and cellular cascade that results in intense local inflammation. ${ }^{5} \mathrm{~A}$ strong impression of familial aggregation of atopy is long standing and the observation that most atopic individuals are sensitised to a range of allergens suggests idiosyncrasy. Though accurate immunoassays exist for the detection of total serum IgE and specific IgE to common allergens, the definition of the atopy phenotype remains a contentious issue within the studies on the genetics of atopy. ${ }^{6}$

\section{Genetics of atopy - a centrist view}

It is agreed that atopy represents a generalised, rather than allergen specific, phenomenon of exuberant IgE production but whether atopic individuals can be recognised by the demonstration of one, two, or more allergen specific IgE responses as well as by raised total serum $\operatorname{IgE}$ (in helminth free environments) is disputed. ${ }^{6}$ In studies, demanding the segregation of these criteria, the summary of genetic observations is as follows.

Total serum IgE concentrations show a continuous skewed distribution and influence by age and smoking that make discrimination between the atopic and non-atopic difficult. ${ }^{7}$ Twin studies, however, comparing similarities or differences between monozygotic and dizygotic twin pairs have consistently suggested a decisive genetic effect with a heritability (that fraction of variation due to genetic factors) of $50-70 \%$ for total serum IgE.$^{89}$ Family studies have proved difficult to interpret, despite the use of complex path and segregation analysis; there is partial, inconclusive evidence that high concentrations of total serum IgE may be transmitted as an autosomal recessive character. ${ }^{1011}$

If discrete elements, though not yet formal epitopes, of specific allergens are identified and IgE response to them tested, then relationships between certain specific responses and different HLA class II genotypes can be demonstrated. ${ }^{12}$ It remains to be shown whether HLA class II molecule variation is deterministic in sensitisation to large complex allergens and in the development of clinical disease.

\section{An Oxford view}

A group in Oxford has taken a contrary view on the identification of atopy, though accepted that the factors controlling generalised atopic response and specific allergen responses must be different; they have concluded that total serum IgE alone, used at any stage, is an insensitive assay for the atopic state. In their studies, individuals are categorised as atopic if they show $\operatorname{IgE}$ response to any one or more common allergens, by skin prick test or immunoassay of circulating specific IgE, or if they show a raised total serum IgE. ${ }^{13}$ Striking vertical transmission of this atopy phenotype was noted. ${ }^{13}$ This implied dominant inheritance, though the results of further studies suggest important genetic heterogeneity and the likelihood that one predominant gene effect, transmitted on chromosome 11 , is subject to genomic imprinting.

In initial linkage studies (matching the transmission of atopy in seven extended families to restriction fragment length polymorphisms of an anonymous DNA marker D11S97), genetic linkage to chromosome $11 \mathrm{q} 13$ was observed with a lod score of $5 \cdot 6 .^{14}$ This observation was replicated, with a lod score of $3 \cdot 8$, in a study of 64 nuclear families recruited via young probands with atopic asthma or rhinitis. ${ }^{15}$

Further analysis of genetic linkage data from nearly 1000 individuals by the method of affected sibling pair analysis confirmed genetic linkage of atopy to chromosome 11 ; sibling pair sharing of $11 \mathrm{q}$ alleles was observed for a variety of definitions of atopy, including high total IgE concentrations used alone. ${ }^{16}$ The data also showed that sharing of parental alleles by siblings derived exclusively from the mother ${ }^{16}$ and that linkage occurred in approximately $60 \%$ of families. ${ }^{15}$ The sharing of maternal alleles alone is likely to be due to genomic imprinting of the, as yet, unidentified locus on chromosome 11. It is clear from the data that other loci at other chromosomal locations must confer atopy in a significant number of families.

The Oxford group also show that there is interaction between chromosome 11 linked atopy and other factors, for example house dust mite load in children's beds, in determining the risk of allergen specific sensitisation and of disease, for example to house dust mite and of asthma. ${ }^{17}$

\section{A conclusion}

What is the status of the Oxford results? Genetic linkage analysis can be confounded by a variety of errors and is essentially a statistical process; any disease linkage observation requires replication. There is one further report of genetic linkage between atopy and chromosome 11 from Japan (with a lod score of $4 \cdot 8$ from four families), ${ }^{18}$ but four other studies (from Britain, America, Japan, and the Netherlands) have failed to detect genetic linkage. ${ }^{19-22}$ Small numbers of families tested, varying methodology, and the undoubted genetic heterogeneity of atopy are likely to explain these different results. ${ }^{23}$ Further studies are needed that include substantial numbers of families; affected sibling pair analysis, which makes no assumptions about mode of inheritance, may be especially valuable in the meta-analysis.

If the loci (including the 11q13 locus) at which mutations can confer atopy or generalised IgE response can be identified, a major step towards a fundamental and molecular understanding of atopy (the principle cause of asthma) will have been taken. This should surely offer the potential for improved treatments and prevention in the future.

JULIAN M HOPKIN

Osler Chest Unit,

Churchill Hospital,

Headington,

Oxford OX3 $7 L \mathcal{F}$

1 Sibbald B, Turner-Warwick $M$. Factors influencing the prevalence of asthma in first degree relatives of extrinsic and intrinsic asthmatics. Thorax 1979; 34: $332-7$

2 Townley RG, Bewtra A, Wilson AF, et al. Segregation analysis of bronchial response to methacholine inhalation challenge in families with and withou asthma. F Allergy Clin Immunol 1986; 77: 101-7.

3 Cooke RA, Vander Veer AJr. Human sensitization. F Immunol 1916; 1: 201305.

4 Stenius B, Wide $\mathrm{L}$, Seymour W, et al. Clinical significance of specific IgE to common allergens. Clinical Allergy 1971; 1: 37-55.

5 Djukanovic R, Roche WR, Wilson JW, et al. Mucosal inflammation in asthma. Am Rev Respir Dis 1990; 142: 434-57.

6 Marsh DG, Meyers DA. A major gene for allergy - fact or fancy? Nature Genetics 1992; 2: 252-4.

7 Holford-Strevens V, Warren P, Wong C, Manfreda J. Serum total IgE levels in Canadian adults. $\mathcal{f}$ Allergy Clin Immunol 1984; 73: 516-22.

8 Bazarel M, Orgel HA, Hamburger RN. Genetics of IgE and allergy: serum IgE levels in twins. F Allergy Clin Immunol 1974; 54: 288-304.

9 Hanson B, McGue M, Roitman-Johnson B, Segal NL, Bouchard TJ, Blumenthal MN. Atopic disease and immunoglobulin $\mathrm{E}$ in twins reared apart and together. Am F Hum Genet 1991; 48: 873-9.

10 Gerrard J, Rao D, Morton N. A genetic study of immunoglobulin E. Am f Hum Genet 1978; 30: 46-58.

11 Blumenthal MN, Namboodiri N, Mendell N, et al. Genetic transmission of serum IgE levels. Am $\mathcal{F}$ Med Genet 1981; 10: 219-28.

12 Ansari AA, Shinomiya N, Zwollo P, Marsh DG. HLA-D gene studies in relation to immune responsiveness to a grass allergen Lol p III. Immunogenetics 1991; 33: 24-32.

13 Cookson WOCM, Hopkin JM. Dominant inheritance of atopic immunoglobulin-E responsiveness. Lancet 1988 ; i: $86-8$.

14 Cookson WOCM, Sharp PA, Faux JA, Hopkin JM. Linkage between immonglobulin E resp PA, Faux JA, Hopkin JM. Linkage between 11q. Lancet 1989; i: 1292-5.

15 Young RP, Sharp PA, Lynch JR, et al. Confirmation of genetic linkage between atopic IgE responses and chromosome 11q13. F Med Genet 1992; 29: 236-8. 16 Cookson WOCM, Young RP, Sandford AJ, et al. Maternal inheritance of atopic IgE responsiveness on chromosome 1lq. Lancet 1992; 340: 381-4.

17 Young RP, Hart BJ, Merret TG, et al. House dust mite allergy: interaction of 
genetic factors and dosage of allergen exposure. Clin Exp Allergy 1992; 22: 205-11.

18 Shirakawa $\mathrm{T}$, Morimoto $\mathrm{K}$, Hashimoto $\mathrm{T}$, et al. Linkage between IgE responses underlying asthma and rhinits (atopy) and chromosome $11 \mathrm{q}$ in Japanese families. XI International Workshop on Human Gene Mapping. ICRF, London. Cytogenet Cell Genet 1991; 3-4: 1970.

19 Hizawa $N$, Ohe $M$, Yamaguchi $E$, et al. Lack of linkage between atopy and locus 1 lq13. Clin Exp Allergy 1992; 22: 1065-90.

20 Rich SS, Roitman-Johnson B, Greenberg B, et al. Genetic analysis of atopy in three large kindreds: no evidence of linkage to D11S97. Clin Exp Allergy 1992; 22: 1070-6.

21 Amelung PJ, Panhuysen CIM, Postma DS, et al. Atopy, asthma and bronchial hyperresponsiveness: exclusion of linkage to markers on chromosomes $11 \mathrm{q}$ and 6p. Clin Exp Allergy 1992; 22: 1077-84.

22 Lympany P, Welsh KI, Cochrane GM, et al. Genetic analysis of the linkage between chromosome 1lq and atopy. Clin Exp Allergy 1992; 22: 1085-92.

23 Moffatt MF, Sharp PA, Faux JA, et al. Factors confounding genetic linkage between atopy and chromosome 1lq. Clin Exp Allergy 1992; 22: 1046-51. 